\title{
FAKTOR-FAKTOR YANG MEMPENGARUHI MINAT MASYARAKAT BALIKPAPAN DALAM MENGGUNAKAAN PRODUK DAN JASA BRILINK
}

\author{
Nurul Musfirah Khairiyah ${ }^{1}$, Dessy Handa Sari $^{2}$ \\ ${ }^{1,2}$ Politeknik Negeri Balikpapan, Balikpapan. \\ dessy.handa@poltekba.ac.id
}

\begin{abstract}
ABSTRAK
PT.Bank Rakyat Indonesia (Persero) Tbk. Kantor cabang Balikpapan merupakan salah satu kantor cabang dari PT.Bank Rakyat Indonesia (Persero), Tbk. Tugasnya adalah menjalankan segala perintah yang telah ditetapkan oleh kantor pusat dan memberikan layanan produk perbankan, termasuk menjadi pengelola BRILink untuk wilayah Balikpapan dan sekitarnya. Tujuan dari penelitian ini adalah untuk mengatahui faktorfaktor yang mempengaruhi minat masyarakat Balikpapan dalam menggunakan produk dan jasa BRILink, dengan menggunakan variabel tempat, variabel pelayanan dan variabel harga sebagai variabel independen dan variabel minat sebagai variabel dependen.Jenis data yang digunakan adalah data primer melalui metode penyebaran kuisioner.Sumber data dalam penelitian ini adalah nasabah agen BRILink yang tersebar di Kota Balikpapan. Hasil penelitian variabel tempat(X1), pelayanan(X2), dan harga(X3) secara simultan berpengaruh signifikan terhadap minat nasabah(Y) melakukan transaksi di BRILink.Variabel tempat(X1) dan harga(X3) berpengaruh signifikan dan berhubungan positif terhadap minat nasabah(Y) melakukan transaksi di BRILink.Variabel pelayanan(X2) tidak berpengaruh dan berhubungan negatif terhadap minat nasabah(Y) melakukan transaksi di BRILink.variabel tempat (X1) merupakan variabel yang paling dominan mempengaruhi minat nasabah dalam melakukan transaksi di agen BRILink dengan angka sumbangan efektif sebesar 35\% dan sumbangan relatif sebesar $75,9 \%$ di antara variabel pelayanan (X2) dan variabel harga (X3).

Kata Kunci: Inklusi Keuangan, BRILink, Minat, Tempat, Pelayanan, Harga
\end{abstract}

\section{PENDAHULUAN}

Fenomena yang di hadapi saat ini adalah perusahaan perbankan hanya mendirikan kantor cabang atau unit kerja di wilayah tertentu yang membuat pelayanan terbatas. Peletakan kantor cabang maupun unit kerja yang hanya dapat dijumpai di daerah pusat kota ini membuat pelayanan hanya terbatas bagi masyarakat yang mempunyai akses yang 
mudah dan dekat dengan kantor tersebut. Perluasan fasilitas transaksi keuangan perbankan seperti halnya mesin ATM pun belum tersedia secara memadai.Dengan dasar biaya yang dinilai mahal untuk mendirikan sebuah Kantor Cabang maupun pelatakan mesin ATM menyebabkan pelayanan perbankan bagi masyarakat Indonesia belum dinikmati secara merata.

PT. Bank Rakyat Indonesia (Persero) Tbk, sebagai bank terkemuka yang dapat menjangkau nasabah hingga pelosok negeri turut serta memperluas jasa perbankan yang dapat dinikmati oleh seluruh nasabah, khususnya bagi nasabah yang memiliki keterbatasan akses untuk menuju kantor cabang maupun unit kerja untuk malakukan transaksi, yaitu melalui Agen BRILink. BRILink merupakan layanan BRI dimana BRI menjalin kerja sama dengan nasabah BRI sebagai agen yang dapat melayani transaksi perbankan bagi masyarakat secara real time online menggunakan fiture EDC Mini ATM BRI dengan konsep sharing fee, BRILink merupakan penerapan dari program laku pandai oleh PT.Bank Rakyat Indonesia yang sesuai dengan peraturan OJK, yaitu program layanan keuangan tanpa kantor untuk keuangan inklusif melalui perantara Agen Bank. Berikut ini adalah data jumlah agen BRILink di Indonesia.

Tabel 1 Jumlah Agen BRILink di Indonesia

\begin{tabular}{|c|c|c|}
\hline No & Tahun & Jumlah Agen \\
\hline 1 & 2015 & 50.259 \\
\hline 2 & 2016 & 84.550 \\
\hline 3 & 2017 & 279.750 \\
\hline 4 & 2018 & 401.550 \\
\hline 5 & 2019 & 422.160 \\
\hline
\end{tabular}

Sumber : Annual Report BRI 2015 - 2019

Memperhatikan data diatas dapat digambarkan bahwa jumlah agen BRILink dari tahun ke tahun terus meningkat rata-rata sebesar 160\%. Agen BRILink di lengkapi dengan adanya mesin ATM mini atau Electronic Data Capture (EDC) BRILink, agen dapat dengan mudah untuk melakukan transfer antar bank, tarik tunai, membayar cicilan, membayar atau pembelian listrik, isi pulsa, membayar tagihan kartu kredit dan lain sebagainya. 
PT. Bank Rakyat Indonesia (Persero), Tbk Kantor Cabang Balikpapan Sudirman merupakan salah satu kantor cabang Bank Rakyat Indonesia yang berada di wilayah kantor BRI Balikpapan yang mensuvervisi 18 kantor unit tersebar di seluruh wailayah Balikpapan serta memiliki 2 kantor cabang pembantu di wilayah Manggar dan Muara Jawa. BRI Balikpapan menunjukkan komitmennya dalam pemenuhan kualitas layanan yang diberikan kepada masyarakat dalam pengembangan kantor unit yang akan memudahkan masyarakat dalam bertransaski perbankan melalui BRI. Bank BRI cabang Balikpapan juga terus mengembangkan dalam peningkatan transaksi, Fee Based Income (FBI) dan laba melalui Agen BRILink.

Berdasarkan latar belakang tersebut, penulis tertarik untuk meneliti lebih lanjut minat masyarakat dalam menggunakan produk dan jasa BRILink, dengan judul penelitian "Faktor-faktor Yang Mempengaruhi Minat Masyarakat Balikpapan Dalam Menggunakaan Produk dan Jasa BRILink"

\section{TINJAUAN PUSTAKA, KERANGKA PEMIKIRAN \& HIPOTESIS}

\section{Tinjauan Pustaka}

\section{Financial Inclusion (Keuangan Inklusif)}

Inklusi keuangan berdasarkan[1] Peraturan Presiden Nomor 82 Tahun 2016 tentang Strategi Nasional Keuangan Inkusif, adalah sebuah kondisi dimana setiap anggota masyarakat mempunyai akses terhadap berbagai layanan keuangan formal yang berkualitas, tepat waktu, lancar dan aman. Dengan biaya terjangkau sesuai dengan kebutuhan dan kemampuan masing-masing.

Keuangan inklusif menjadi penting dan mendesak karena masih banyaknya jumlah penduduk Indonesia yang belum memiliki akses ke sektor keuangan formal.Ditambah lagi bahwa sektor keuangan formal merupakan barang publik dan oleh karenanya setiap warga negara berhak untuk mengakses berbagai produk dan jasa keuangan formal yang berkualitas, tepat waktu, nyaman, jelas dan dengan biaya yang terjangkau. Oleh karena itu, akses terhadap produk dan jasa keuangan formal harus diberikan bagi semua segmen masyarakat, dengan perhatian khusus kepada kelompok miskin yang berpenghasilan rendah, kelompok miskin produktif, kelompok pekerja migran dan kelompok masyarakat yang tinggal di daerah terpencil[2]. 


\section{Minat Nasabah}

Minat merupakan suatu keinginan yang ditimbulkan dari diri sendiri tanpa adanya paksaan dari orang lain untuk mencapai suatu tujuan tertentu. Minat adalah rasa suka, rasa senang dan rasa tertarik pada suatu objek atau aktivitas tanpa adanya yang menyeluruh dan biasanya ada kecendrungan untuk mencari kembali objek yang disukai tersebut. Minat lebih dikenal sebagai keputusan seseorang untuk menggunakan atau membeli jasa/produk tertentu [3]

\section{BRILink}

Agen BRIlink merupakan layanan agen laku pandai milik bank BRI yang diluncurkan pada November 2014.Dengan menggandeng pihak ketiga dalam hal ini nasabah BRI sebagai agen, agen BRILink memberikan pelayanan jasa perbankan bagi masyarakat baik nasabah BRI maupun nasabah non BRI.

Agen BRILink dapat melayani kebutuhan masyarakat akan berbagai transaksi perbankan seperti setor dan tarik tunai, pembayaran angsuran pinjaman BRI, transfer antar bank, pembelian pulsa telepon, token listrik PLN dan berbagai layanan lainnya [4]. Jadi, tujuan Bank BRI meluncurkan program BRILink adalah untuk memudahkan masyarakat dalam menggunakan jasa perbankan tanpa menunggu antrian di kantor bank dan dapat melayani 24 jam setiap hari.

\section{Penelitian Terdahulu}

Dalam melakukan penelitian, penulis mempelajari beberapa penelitian terdahulu untuk mendapatkan gap riset yang tepat didukung oleh refrensi dari penelitian sebelumnya :

Tabel 2 Daftar Penlitian terdahulu

\begin{tabular}{|l|l|l|l|l|}
\hline No & \multicolumn{1}{|c|}{ Peneliti } & \multicolumn{1}{|c|}{ Variabel } & \multicolumn{1}{|c|}{ Hasil } & Responden \\
\hline 1 & Rizal Mahdi, & Daya tarik produk, & Keputusan bertransaksi & 110 \\
& Harry & daya tarik pelanggan, & secara statistik terbukti & Responden \\
& Soesanto[5] & daya saing tarif, & dipengaruhi oleh keputusan & \\
& & kepuasan nasabah, & nasabah, kepuasan nasabah & \\
& dan keputusan & secara statistik terbukti & \\
& bertransaksi. & dipengaruhi oleh daya tarik & \\
& & $\begin{array}{l}\text { layanan dan daya saing tarif } \\
\text { sedangkan daya tarif produk }\end{array}$ & \\
\hline
\end{tabular}




\begin{tabular}{|c|c|c|c|c|}
\hline & & & $\begin{array}{l}\text { tidak terbukti berpengaruh } \\
\text { signifikan. }\end{array}$ & \\
\hline 2 & $\begin{array}{l}\text { Nindya } \\
\text { Linggar Amita } \\
{[6]}\end{array}$ & $\begin{array}{l}\text { Kegunaan, } \\
\text { Kemudahan, Resiko } \\
\text { dan Minat }\end{array}$ & $\begin{array}{l}\text { Presepsi kegunaan, persepsi } \\
\text { kemudahan, dan persepsi } \\
\text { resiko memiliki pengaruh } \\
\text { yang signifikan terhadap } \\
\text { minat menggunakan layanan } \\
\text { BRILink. }\end{array}$ & $\begin{array}{l}130 \\
\text { Responden }\end{array}$ \\
\hline 3 & $\begin{array}{l}\text { Akhmad } \\
\text { Faisol [7] }\end{array}$ & $\begin{array}{l}\text { Budaya, Harga, } \\
\text { Lokasi terhadap } \\
\text { Minat Belanja }\end{array}$ & 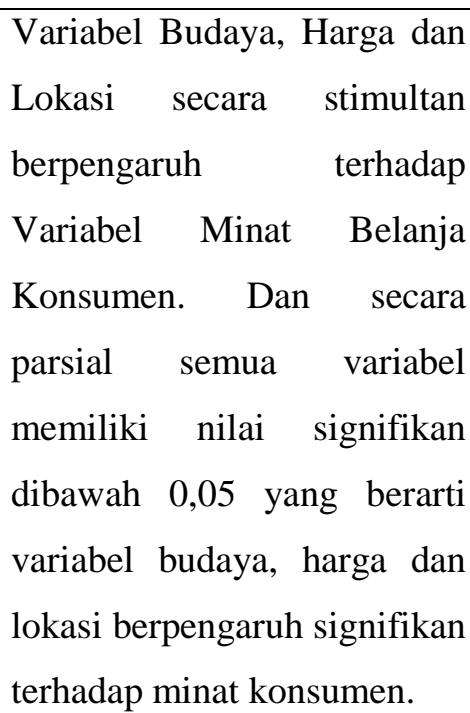 & $\begin{array}{l}80 \\
\text { Responden }\end{array}$ \\
\hline 4 & $\begin{array}{ll}\text { Faradiba, } & \text { Sri } \\
\text { Rahayu } & \text { Tri } \\
\text { Astuti[8] } & \end{array}$ & $\begin{array}{l}\text { Kualitas, Harga, } \\
\text { Lokasi, Pelayanan } \\
\text { dan Minat beli ulang }\end{array}$ & $\begin{array}{l}\text { Hasil penelitian ini } \\
\text { menunjukkan bahwa kelima } \\
\text { variabel memiliki pengaruh } \\
\text { positif terhadap minat beli } \\
\text { ulang konsumen. } \\
\text { Yang memiliki pengaruh } \\
\text { paling tinggi adalah kualitas } \\
\text { produk, kemudian diikuti } \\
\text { lokasi, kualitas pelayanan } \\
\text { dan harga. Didalam } \\
\text { penelitian ini variabel terikat } \\
\text { (minat beli ulang konsumen) } \\
\text { dapat dijelaskan oleh } \\
\text { variabel bebas ( kualitas } \\
\text { produk, harga, lokasi, dan } \\
\text { kualitas pelayanan) sebesar }\end{array}$ & 100 Orang \\
\hline
\end{tabular}




\begin{tabular}{|l|l|l|}
\hline & $\begin{array}{l}49,8 \% \text { dan } 50,2 \% \text { dijelaskan } \\
\text { variabel bebas diluar } \\
\text { penelitian ini. }\end{array}$ \\
\hline
\end{tabular}

Sumber : Hasil Olahan

\section{Kerangka Berfikir}

Kerangka penelitian ini adalah untuk menguji variabel independen terhadap variabel dependen. Maka dibuat suatu kerangka pemikiran sebagai berikut:

\section{Gambar 1}

\section{Model Penelitian}

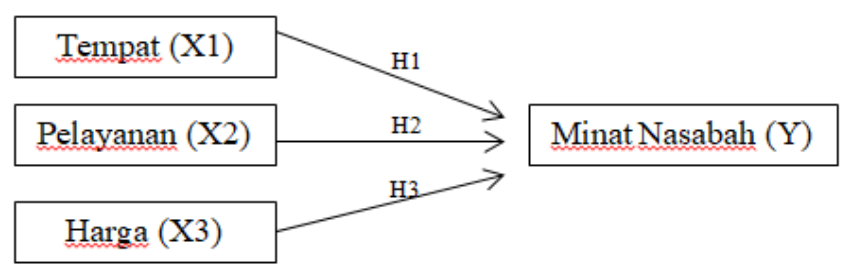

\section{Hipotesis}

Maka hipotesis dari penelitian ini yaitu :

$\mathrm{H}^{1}$ :Variabel Tempat (X1) berhubungan positif dan berpengaruh signifikan terhadap minat masyarakat dalam menggunakan produk dan jasa BRILink di kota Balikpapan

$\mathrm{H}^{2}$ :Variabel Pelayanan (X2) berhubungan positif dan berpengaruh signifikan terhadap minat masyarakat dalam menggunakan produk dan jasa BRILink di kota Balikpapan $\mathrm{H}^{3}$ :Variabel Harga (X3) berhubungan positif dan berpengaruh signifikan terhadap minat masyarakat dalam menggunakan produk dan jasa BRILink di kota Balikpapan

\section{METODE PENELITIAN}

\section{Desain Penelitian}

Teknik pengolahan data menggunakan perhitungan komputerisasi program SPSS. Analisis data dilakukan dengan tujuan untuk menguji hipotesis dalam rangka penarikan kesimpulan.Metode analisis data dalam penelitian ini menggunakan metode analisis statistik deskriptif, analisis regresi dan korelasi linear berganda dan melakukan pengujian hipotesis.Variabel penelitian yang digunakan dalam penelitian ini adalah variabel dependen yaitu minat (Y). Sedangkan variabel independenya adalah tempat (X1), pelayanan (X2) dan harga (X3) 


\section{Operasional Variabel}

\section{Variabel Minat (Y)}

Suatu keinginan (minat) seseorang untuk melakukan transaksi perbankan di Agen BRILink kota Balikpapan dengan indikator penilaian frekuensi transaksi, pengaruh orang terdekat, syarat dan kemudahan transaksi

\section{Variabel Tempat (X1)}

Kemudahan nasabah Agen BRILink kota Balikpapan dalam menjangkau dan menemukan lokasi agen BRILink yang dilihat dari aspek lokasi, kemudahan, ukuran kantor, keberadaan yang strategis, keamanan dan dekat dengan tempat tinggal.

\section{Variabel Pelayanan (X2)}

Pelayanan yang diberikan oleh Agen BRILink Balikpapan kepada nasabah Agen BRILink kota Balikpapan yang di nilai oleh pemberian informasi yang jelas oleh petugas ke nasabah, pelayanan yang cepat dan tepat, keadilan terhadap setiap nasabah dan rasa nyaman.

\section{Variabel Harga (X3)}

Harga atau biaya yang ditetapkan oleh Agen BRIlink kota Balikpapan dalam setiap transaksi keuangan apakah harga atau biaya sesuai dengan manfaat yang diperoleh, yaitu berupa biaya yang terjangkau oleh masyarakat dan persetujuan konsumen dengan biaya jasa yang di tawarkan

\section{HASIL DAN PEMBAHASAN}

Kuisioner yang disebar dalam penelitian ini sebanyak 142 kuisioner.Dari kuisioner tersebut sebanyak 141 kuisioner yang kembali dan hanya 129 kuisioner yang lengkap, sesuai kriteria dan dapat dianalisis.Hal tersebut menunjukkan bahwa dalam mengisi kuisioner responen tidak berhati-hati ketika melihat pertanyaan yang diajukan.

\section{Analisis dan Hasil Interpretasi}

\section{Hasil uji instrument penelitian}

\section{Uji validitas}

Uji validitas dilakukan dengan menggunakan SPSS versi 20 yang bertujuan untuk mengukur valid tidaknya setiap pertanyaan yang diajukan kepada resonden.Teknik yang 
dipakai dalam penelitian ini adalah teknik korelasi yaitu membandingkan koeresien korelasi rhitung dan rtabel.Jika koefesien rhitung lebih besar dari rtabel maka pernyataan kuisioner ini dikatakan valid. Hasil uji validitas dari setiap item pernyataan seperti dibawah ini :

Tabel 3

Hasil Uji Validitas

\begin{tabular}{|c|c|c|c|}
\hline \multicolumn{4}{|c|}{ X1 } \\
\hline Pertanyaan & $\begin{array}{l}\text { Corrected Item- } \\
\text { Total Correlation }\end{array}$ & $\begin{array}{r}\text { Nilai R } \\
\text { Tabel }\end{array}$ & Keterangan \\
\hline 1 & 0.753 & 0,224 & Valid \\
\hline 2 & 0.728 & 0,224 & Valid \\
\hline 3 & 0.671 & 0,224 & Valid \\
\hline 4 & 0.654 & 0,224 & Valid \\
\hline 5 & 0.679 & 0,224 & Valid \\
\hline 6 & 0.603 & 0,224 & Valid \\
\hline \multicolumn{4}{|c|}{$\mathbf{X 2}$} \\
\hline 1 & 0.531 & 0,224 & Valid \\
\hline 2 & 0.584 & 0,224 & Valid \\
\hline 3 & 0.625 & 0,224 & Valid \\
\hline 4 & 0.758 & 0,224 & Valid \\
\hline 5 & 0.641 & 0,224 & Valid \\
\hline 6 & 0.743 & 0,224 & Valid \\
\hline \multicolumn{4}{|c|}{$\mathbf{X 3}$} \\
\hline 1 & 0.640 & 0,224 & Valid \\
\hline 2 & 0.797 & 0,224 & Valid \\
\hline 3 & 0.768 & 0,224 & Valid \\
\hline 4 & 0.784 & 0,224 & Valid \\
\hline 5 & 0.780 & 0,224 & Valid \\
\hline \multicolumn{4}{|c|}{$\mathbf{Y}$} \\
\hline 1 & 0.814 & 0,224 & Valid \\
\hline 2 & 0.764 & 0,224 & Valid \\
\hline 3 & 0.722 & 0,224 & Valid \\
\hline 4 & 0.787 & 0,224 & Valid \\
\hline 5 & 0.777 & 0,224 & Valid \\
\hline
\end{tabular}




\begin{tabular}{|l|l|l|l|}
\hline 6 & 0.710 & 0,224 & Valid \\
\hline 7 & 0.750 & 0,244 & Valid \\
\hline
\end{tabular}

Sumber : Olahan,2020

Dari hasil perhitungan koefesien korelasi seluruhnya mempunyai $r_{\text {hitung }}$ lebih besar dari $\mathrm{r}_{\text {tabel }}(0,224)$.Dengan demikian dapat disimpulkan bahwa seluruh pernyataan pada instrument dapat dinyatakan layak sebagai instrument guna mengukur penelitian minat bertransaksi.

\section{Uji reliabilitas}

Selain uji validitas, dalam pernyataan yang dibagikan kepada responden juga dilakukan uji reliailitas untuk menunjukkan ke-konsistensian jawaban dari responden dan dikatakan reliable jika alpha lebih dari 0,6. Berikut ini adalah hasil uji reliabilitas masing-masing variabel.

\section{Tabel 4}

\section{Hasil Uji Reliabilitas}

\begin{tabular}{|c|c|c|c|}
\hline Variabel & Cronbach's Alpha & Nilai Kritis & Keterangan \\
\hline X1 & 0.766 & 0.60 & Reliabel \\
\hline X2 & 0.882 & 0.60 & Reliabel \\
\hline X3 & 0.806 & 0.60 & Reliabel \\
\hline Y & 0.866 & 0.60 & Reliabel \\
\hline
\end{tabular}

Sumber : Olahan, 2020

\section{Hasil uji asumsi klasik}

\section{Uji Normalitas}

Uji normalitas digunakan untuk menguji apakah dalam model regresi variabel pengganggu residual memiliki distribusi normal. Untuk mengetahui normal atau tidaknya bisa dilihat pada grafik titik-titik yang menyebar disekitar garis diagonal serta penyebarannya mengikuti arah garis diagonal, maka regresi layak pakai, serta jika penyebarannya tidak mengikuti arah garis diagonal, maka regresi tidak layak pakai. 


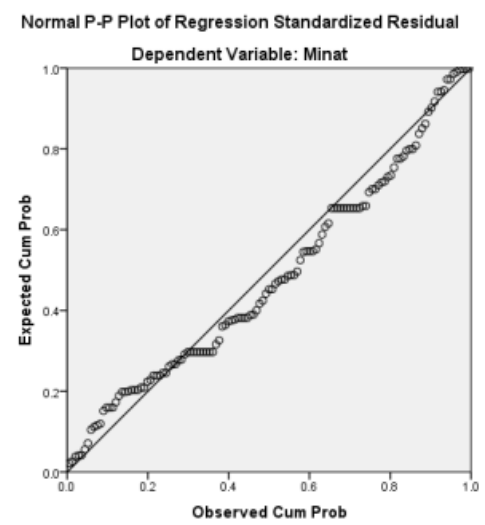

Sumber : Olahan, (2020)

Gambar 4.1

Hasil uji normalitas

Dari grafik diatas menunjukkan bahwa grafik titik-titik yang menyebar disekitar garis diagonal serta penyebarannya mengikuti arah garis diagonal sehingga model regresi layak digunakan.

\section{Uji multikolinearitas}

Uji multikolinearitas dipakai untuk mengetahui apakah model regresi menemukan adanya korelasi antar variabel bebas (independen).Multikolinearitas dapat dilihat dari variance inflation factor (VIF) dan nilai tolerance. Multikolinearitas terjadi jika tolerance 0,10 atau sama dengan VIF 10. Jika nilai VIF tidak melebihi 10, maka dapat dikatakan bahwa multikolinearitas terjadi tidak berbahaya (lolos uji).Adapun hasil dari ji multikolinearitas adalah sebagai berikut :

Tabel 4.5

Hasil uji nilai tolerance dan VIF

\begin{tabular}{|l|c|c|c|}
\hline \multicolumn{1}{|c|}{ Variabel Independen } & Tolerance & VIF & Keterangan \\
\hline Tempat & 0.433 & 2.331 & Tidak terjadi multikolinearitas \\
\hline Pelayanan & 0.420 & 2.380 & Tidak terjadi multikolinearitas \\
\hline Harga & 0.542 & 1.846 & Tidak terjadi multikolinearitas \\
\hline
\end{tabular}

Sumber : Olahan,2020

Berdasarkan pada hasil tabel di atas tidak terdapat variabel yang mempunyai nilai VIF lebih dari 10 dan nilai tolerance yang lebih kecil dari $10 \%$. Hasil tersebut menunjukkan bahwa model regresi tidak memiliki gejala multikolinearitas. 


\section{Uji Heterokesdasitas}

Uji heterokesdasitas digunakan untuk mengetahui apakah dalam model regresi terjadi ketidaksamaan variance dari residual satu pengamatan ke pengamatan yang lain. Jika satu pengamatan ke pengamatan yang lain tetap, maka disebut homoskedasitas dan apabila berbeda disebut heterokesdasitas. Untuk mengetahui dapat dilihat pada scatterplot sebagai berikut :

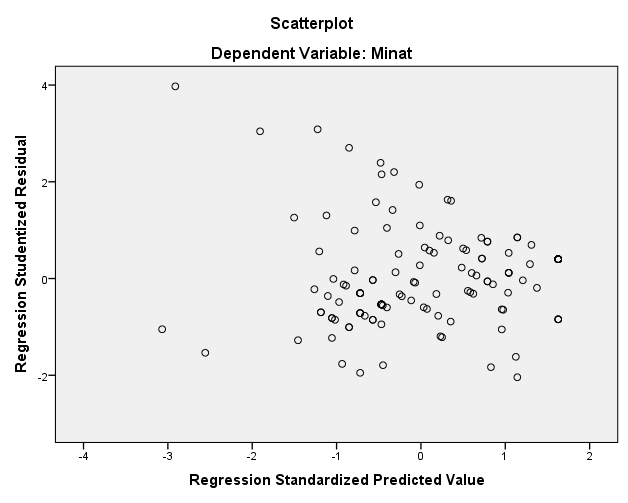

Sumber : Olahan, 2020

Gambar 4.2

Hasil uji Heterokesdasitas

Dari hasil uji yang terlihat pada plot diatas, dapat disimpulkan bahwa tidak terjadi heterokesdasitas.Karena titik-titik pada area grafik menyebar baik di atas ataupun dibawah angka nol pada sumbu Y. Sehingga model regres layak digunakan untuk memprediksi minat penggunaan berdasarkan masukan variabel independen.

\section{Hasil Regresi Linear Berganda}

\section{Analisis regresi linear berganda}

Analisis regresi berganda digunakan untuk mengetahui pengaruh variabel bebas secara bersama-sama terhadap variabel terikat.Analisis ini untuk mengetahui hubungan antara variabel independen dengan variabel dependen berhubungan positif atau negatif dan untuk memprediksi nilai dari variabel dependen apabila nilai variabel independen mengalami kenaikan atau penurunan. 
Tabel 4.6

\section{Hasil uji regresi Linear Berganda}

Coefficients $^{\mathrm{a}}$

\begin{tabular}{|l|c|c|c|c|c|}
\hline \multirow{2}{*}{ Model } & \multicolumn{2}{|c|}{$\begin{array}{c}\text { Unstandardized } \\
\text { Coefficients }\end{array}$} & $\begin{array}{c}\text { Standardized } \\
\text { Coefficients }\end{array}$ & $\mathrm{t}$ & Sig. \\
\cline { 2 - 6 } & $\mathrm{B}$ & Std. Error & Beta & & \\
\hline (Constant) & 7.546 & 2.342 & & 3.222 & .002 \\
\hline Tempat & .716 & .130 & .547 & 5.504 & .000 \\
\hline Pelayanan & -.148 & .119 & -.125 & - & .216 \\
\hline Harga & .377 & .111 & .302 & 3.403 & .001 \\
\hline
\end{tabular}

a. Dependent Variable: Minat

Berdasarkan uji regresi linear berganda, dapat diperoleh persamaan regresi sebagai berikut :

$$
\mathrm{Y}=7.546+0.716 X 1-0.148 X 2+0.377 X 3
$$

\section{Uji Simultan (Uji F)}

Uji simultan atau Uji $\mathrm{F}$ digunakan untuk mengetahui pengaruh variabel secara bersamaan terhadap variabel dependen.Adapun pengujian dalam uji $\mathrm{F}$ ini yaitu dengan menggunakan suatu tabel yang disebut dengan tabel ANOVA dengan melihat uji signifikansi (sig. > 0.05 atau 5\%) maka H1 ditolak, sebaliknya jika nilai signifikansi < 0.05 maka H1 diterima. Adapun hasil Uji F adalah sebagai berikut :

Tabel 4.7

\section{Hasil uji Simultan (Uji F)}

ANOVA $^{\mathrm{a}}$

\begin{tabular}{|c|c|c|c|c|c|}
\hline Model & $\begin{array}{l}\text { Sum of } \\
\text { Squares }\end{array}$ & df & Mean Square & $\mathrm{F}$ & Sig. \\
\hline Regression & 651.834 & 3 & 217.278 & 36.21 & $.000^{\mathrm{b}}$ \\
\hline Residual & 750.042 & 125 & 6.000 & & \\
\hline Total & 1401.876 & 128 & & & \\
\hline
\end{tabular}

a. Dependent Variable: Minat

b. Predictors: (Constant), Harga, Tempat, Pelayanan 
Dari hasil perhitungan pada tabel di atas diperoleh nilai Fhitung 36.628 dengan tingkat signifikansi 0.000.Karena tingkat signifikansi lebih kecil dari 0.05 maka Hipotesis diterima atau dengan $F_{\text {hitung }} 35.628$ lebih besar dari $F_{\text {tabel }}$ 2.676.maka dapat disimpulkan bahwa secara simultan terdapat pengaruh signifikan antara variabel Harga, pelayanan dan tempat terhadap minat nasabah Agen BRILink. Sehingga model regresi signifikan atau dapat diterima.

\section{Uji signifikan parsial (Uji t)}

Uji signifikan (Uji t) digunakan untuk mengetahui tingkat pengaruh antara masingmasing variabel independen secara parsial terhadap variabel dependen. Uji $t$ dilaksanakan dengan membandingkan nilai $t_{\text {hitung }}$ dengan $t_{\text {tabel }}$ (129-3) pada tingat signifikansi 0.05 yaitu sebesar $\mathrm{df}=1.979$. jika $\mathrm{t}_{\text {hitung }}$ lebih besar dari $\mathrm{t}_{\text {tabel }}$ sebesar 1.979 atau nilai signifikansinya kurang dari 0.05 maka variabel bebas (X) berpengaruh signifikan terhadap variabel terikat (Y) secara parsial. Adapun hasil uji dapat diliihat pada tabel berikut :

1. Uji t terhadap variabel tempat

Hipotesis pertama penelitian ini menduga bahwa variabel tempat berpengaruh signifikan dan berhubungan positif terhadap minat nasabah melakukan transaksi di BRILink. Hipotesis secara sistematis dirumuskan sebagai berikut :

$\mathrm{H}^{0}=$ Tempat tidak berpengaruh terhadap minat nasabah dalam melakukan transaksi di Agen BRILink

$\mathrm{H} 1$ = Tempat berpengaruh signifikan terhadap minat nasabah dalam melakukan transaksi di Agen BRILink

Nilai koefesien untuk X1(tempat) sebesar 0.716 dengan demikian setiap peningkatan variabel tempat sebesar 1 satuan dengan asumsi variabel lain tetap maka akan meningkatkan minat dalam melakukan transaksi sebesar 0.716. Nilai signifikansi variabel tempat sebesar 0,000 artinya lebih kecil dari 0,005 dan Nilai $t_{\text {hitung }} \mathrm{X} 1=$ 5.504, $t_{\text {tabel }} 1,979$, sehingga $t_{\text {hitung }}>t_{\text {tabel }}$, Maka H1 diterima sehingga dapat disimpulkan bahwa variabel tempat berpengaruh secara parsial terhadap minat nasabah melakukan transaksi di Agen BRILink 
2. Uji t terhadap variabel pelayanan

Hipotesis kedua penelitian ini menduga bahwa persepsi pelayanan berpengaruh signifikan dan berhubungan positif terhadap minat nasabah melakukan transaksi di BRILink. Hipotesis secara sistematis dirumuskan sebagai berikut :

HO = Pelayanan tidak berpengaruh terhadap minat nasabah dalam melakukan transaksi di Agen BRILink

$\mathrm{H} 2$ = Pelayanan berpengaruh signifikan terhadap minat nasabah dalam melakukan transaksi di Agen BRILink

Nilai koefesien untuk X2 (Pelayanan) sebesar -0.148 dengan demikian setiap peningkatan variabel pelayanan sebesar 1 satuan dengan asumsi variabel lain tetap maka akanmenurunkan minat dalam melakukan transaksi sebesar 0.148.

Nilai signifikansi variabel pelayanan 0,216 yang artinya lebih besar dari 0,055, Nilai $t_{\text {hitung }} X 2=-1.242$ dan $t_{\text {tabel }} 1,979$, sehingga $t_{\text {hitung }}<t_{\text {tabel }}$, Maka H0 diterima sehingga dapat disimpulkan bahwa variabel pelayanan secara parsial tidak berpengaruh terhadap minat nasabah melakukan transaksi di Agen BRILink

3. Uji t terhadap variabel Harga

Hipotesis ketiga penelitian ini menduga bahwa persepsi harga berpengaruh positif terhadap minat nasabah melakukan transaksi di BRILink. Hipotesis secara sistematis dirumuskan sebagai berikut :

$\mathrm{H} 0=$ Harga tidak berpengaruh terhadap minat nasabah dalam melakukan transaksi di Agen BRILink

H3 = Harga berpengaruh terhadap minat nasabah dalam melakukan transaksi di Agen BRILink

Nilai koefesien untuk X3(Harga) sebesar 0.377 dengan demikian setiap peningkatan variabel harga sebesar 1 satuan dengan asumsi variabel lain tetap maka akan meningkatkan minat dalam melakukan transaksi sebesar 0.377 .

Nilai signifikasi variabel 0,001 lebih kecil 0,05. Nilai $t_{\text {hitung }} \mathrm{X} 3=3,403$ dan $t_{\text {tabel }}$ 1,979, sehingga $t_{\text {hitung }}>t_{\text {tabel }}$, Maka H0 ditolak sehingga dapat disimpulkan bahwa variabel harga berpengaruh secara parsial terhadap minat nasabah melakukan transaksi di Agen BRILink 


\section{Hasil perhitungan koefesien determinasi}

Koefisien determinsi (R2) digunakan untuk menngukur seberapa besar variabel bebas $\mathrm{X}$ memberikan pengaruh terhadap variabel terikat $(\mathrm{Y})$ dari persamaan regresi yang didapat. Nilai koefisien determinasi (R2) antara nol dan satu. Apabila angka 0 mendekati 1, berarti indikator yang digunakan semakin kuat pengaruh perubahan variabel-variabel X terhadap perubahan variabel Y. Sebaliknya, apabil koefisien determinasi semakin kecil atau mendekati nol maka semakin kecil pengaruh variabel independen terhadap variabel dependen. Adapun hasil uji adjusted R Square adalah sebagai berikut :

\section{Tabel 4.8}

Model Summary ${ }^{\mathrm{b}}$

\begin{tabular}{|c|c|c|c|c|}
\hline Model & $\mathrm{R}$ & $\mathrm{R}$ Square & $\begin{array}{c}\text { Adjusted R } \\
\text { Square }\end{array}$ & $\begin{array}{c}\text { Std. Error of } \\
\text { the Estimate }\end{array}$ \\
\hline 1 & $.682^{\mathrm{a}}$ & .465 & .452 & 2.450 \\
\hline
\end{tabular}

a. Predictors: (Constant), Harga, Pelayanan, Tempat

b. Dependent Variable: Minat

Dari angka diatas nilai koefisien determinasi atau R Square adalah 0,465. Nilai squre berasal dari pengkuadratan koefesien korelasi " $R$ " atau 0,682 x 0,682 =0,465, besarnya angka koefesien determinasi adalah 0,465 atau sama dengan 46,5\%. Angka tersebut mengandung arti bahwa variabel tempat, pelayanan dan harga secara simultan berpengaruh sebesar $46,5 \%$ sisa $(100 \%-46,5)=53,5$ dipengaruhi oleh variabel lain diluar persamaan regresi ini atau variabel lain yang tidak diteliti. Adapun angka koefisien korelasi $\mathrm{R}$ menunjukkan nilai sebesar 0.682 yang menandakan bahwa hubungan antara variabel bebas dan terikat adalah kuat karena memiliki nilai lebih dari $0.5(\mathrm{R}>0.5)$ atau $0.682>0.5$.

\section{Uji sumbangan relatif (SR) dan sumbangan efektif (SE)}

Sumbangan relatif digunakan untuk mengetahui besarnya sumbangan masing-masing variabel bebas terhadap prediksi.Perhitungan ini dilakukan agar dapat diketahu besarnya sumbangan masing-masing variabel bebas terhadap variabel terikat secara keseluruhan. Sumbangan relatif menghitung besarnya sumbangan masing-masing variabel bebas tanpa memperhatikan variabel lain yang tidak diteliti pada penelitian ini, sehingga besarnya sumbangan masing-masing variabel bebas dapat diprediksi. 
Sumbangan efektif digunakan untuk mengetahui besarnya sumbangan efektif tiap predictor atau variabel bebas dari keseluruhan prediksi.Perhitungan ini dilakukan agar dapat diketahui besarnya sumbangan masing-masing variabel bebas terhadap variabel terikat, sehingga sumbangan yang diberikan masing-masing variabel bebas dapat dilihat.Sumbangan efektif dihitung dengan memperhatikan variabel bebas lainnya yang tidak diteliti pada penelitian ini.

Tabel 4.8

Ringkasan hasil korelasi dan regresi

\begin{tabular}{|c|c|c|c|}
\hline Variabel & $\begin{array}{c}\text { Koefisien Regresi } \\
\text { (Beta) }\end{array}$ & $\begin{array}{c}\text { Koefisien Korelasi } \\
(\mathbf{r})\end{array}$ & R square \\
\hline $\mathrm{X} 1$ & 0.547 & 0.645 & 0.465 \\
\hline $\mathrm{X} 2$ & -0.125 & 0.463 & \\
\hline $\mathrm{X} 3$ & 0.302 & 0.563 & \\
\hline
\end{tabular}

Sumber : Olahan,2020

Perhitungan sumbangan efektif :

$\mathrm{SE}(\mathrm{X})=\operatorname{Beta} \mathrm{X} 1 * \operatorname{rxy} * 100 \%$

$\mathrm{X} 1=0.547 \times 0.645 \times 100 \%=0.3528$

$\mathrm{X} 2=-0.125 \times 0.463 \times 100 \%=0.0578$

$\mathrm{X} 3=0.302 \times 0.563 \times 100 \%=0.1700$

Total Sumbangan efektif $\quad=0.465$ (Sama dengan jumlah R Square)

Perhitungan sumbangan relatif :

$\mathrm{SR}=\mathrm{SE} \% / \mathrm{R}$ Square

$\mathrm{X} 1=35,28 \% / 0.465=75,9$

$\mathrm{X} 2=57,8 \% / 0.465=-12,4$

$\mathrm{X} 3=17 \% / 0.465=36,6$

Total Sumbangan Relatif $=100 \%$

Berdasarkan hasil perhitungan SE dan SR dapat dijelaskan bahwa variabel tempat (X1) merupakan variabel yang paling dominan mempengaruhi minat nasabah dalam melakukan transaksi di agen BRILink dengan angka sumbangan efektif sebesar 35\% dan sumbangan relatif sebesar 75,9\% di antara variabel pelayanan (X2) dan variabel harga (X3). 


\section{Pembahasan hasil penelitian}

a. Pengaruh tempat terhadap minat bertansaksi di Agen Brilink

Berdasarkan hasil uji parsial atau uji t menunjukan bahwa nilai $\mathrm{t}$ hitung > dari pada $\mathrm{t}$ tabel $(5,504>1,979)$ dan nilai signifikan lebih kecil dari 0,05 yaitu 0,00 sehingga $(\mathrm{H} 1)$ menyatakan terdapat pengaruh antara tempat terhadap minat bertansaksi di agen BRILink diterima. Artinya semakin mudah lokasi agen BRILink di jangkau semakin tinggi pula minat masyarakat untuk bertansaksi di agen BRILink.

Hasil penelitian ini sejalan dengan hasil penelitian yang dilakukan oleh Muntasir [9] yang menyatakan bahwa lokasi berpengaruh siginfikan terhadap minat nasabah karena lokasi mudah dijangkau dari tempat tinggal. Sejalan dengan penelitian yang dilakukan oleh Jane Andoko [10] yang menyatakan bahwa faktor yang mempengaruhi minat beli calon konsumen lokasi yang berpengaruh positif dan signifikan dan menurut hasil penelitian Hendra Fure menunjukkan bahwa lokasi berpengaruh signifikan terhadap minat beli konsumen, pemilihan lokasi mempunyai fungsi yang strategis karena dapat ikut menentukan tercapainya tujuan badan usaha[11].

Hal ini menunjukan bahwa tempat memiliki kontribusi yang penting terhadap minat konsumen untuk bertansaksi di agen BRILink.Tempat merupakan salah satu faktor terbesar yang meningkatkan minat konsumen untuk bertansaksi di Agen Brilink, dengan lokasi yang mudah dijangkau, dan dekat dengan pusat keramaian, atapun dekat dengan tempat tinggal sehingga memudahkan konsumen untuk bertansaksi perbankan di Agen BRILink. Dan dengan adanya Agen BRILink di sekitar tempat tinggal ataupun lokasi yang mudah di jangkau, minat masyarakat dalam menggunakan produk perbankan akan meningkat dan memudahkan masyarakat melakukan transaksi perbankan melalui Agen BRILink.

b. Pengaruh Pelayanan terhadap minat transaksi di Agen Brilink

Berdasarkan hasil uji parsial atau uji t menunjukan bahwa nilai t hitung < dari pada $\mathrm{t}$ tabel $(-1,242<1,979)$ dan nilai signifikan lebih besar dari 0,05 yaitu 0,216 sehingga (H0) menyatakan tidak terdapat pengaruh antara pelayanan terhadap minat bertansaksi di agen BRILink diterima. Artinya pelayanan yang terjadi di Agen BRILink tidak mempengaruhi minat masyarakat untuk bertansaksi di Agen BRILink.

Hal ini menunjukan bahwa pelayanan tidak memiliki kontribusi yang penting terhadap minat konsumen untuk bertansaksi di agen BRILink. Pelayanan yang ada di Agen 
BRILink tidak mempengaruhi minat konsumen untuk bertransaksi di Agen Brilink hal ini dapat dikaitkan bahwa sebagian besar yang memiliki Agen BRILink adalah orang yang bergelut di bidang UMKM, atau memiliki toko, sehingga pelayanan yang diberikan seperti pelayanan kebutuhan yang ada di toko,

Hasil penelitian ini tidak sejalan dengan penelitian yang dilakukan oleh Muntasir [9] yang menyatakan bahwa pegawai memberikan informasi dan pelayanan yang baik untuk nasabah, pegawai memberikan informasi dan pelayanan yang baik, sehingga pelayanan sangat mempengaruhi minat nasabah secara signifikan. Dan st.Nur Amalia (2019) yang menyatakan bahwa kualitas pelayanan memiliki pengaruh yang signifikan terhadap keputusan pembelian jasa BRILink dan penelitian yang dilakukan oleh Rizal Mahdi, dkk[5] yang menyatakan bahwa kualitas layanan diketahui memiliki pengaruh besar pada tingkat kepuasan nasabah, hal ini karena nasabah ingin diperlakukan dengan baik agar mereka merasa dihargai, namun jika nasabah diperlakukan dengan tidak nyaman, maka mereka cenderung akan menaruh kekecewaan dan menceritaan pengalaman kepada orang lain. Pelayanan petugas agen BRILink tidak memiliki pengaruh terhadap minat nasabah dalam melakukan transaksi di agen BRILink, hal ini disebabkan karena agen BRILink memiliki sampingan usaha seperti toko kelontong, counter pulsa isi ulang dan agen bantuan sembako. Sehingga dalam pelayanan menyamaratakan semua jenis pelayanan toko dan pelayanan perbankan.

c. Pengaruh harga terhadap minat bertansaksi di Agen BRILink

Berdasarkan hasil uji parsial atau uji t menunjukan bahwa nilai t hitung > dari pada $\mathrm{t}$ tabel $(3,403>1,979)$ dan nilai signifikan lebih kecil dari 0,05 yaitu 0,001 sehingga (H3) menyatakan terdapat pengaruh antara harga terhadap minat bertansaksi di agen BRILink diterima. Artinya semakin terjangkau harga yang ditawarkan semakin tinggi pula minat masyarakat untuk bertansaksi di agen BRILink.

Hasil penelitian ini sesuai dengan hasil penelitian yang dilakukan oleh Rizal Mahdi, $\mathrm{dkk}$ [5] yang menyatakan dimensi pembentuk daya saing tarif berpengaruh terhadap tingkat kepuasan nasabah BRILink, hal tersebut menunjukkan bahwa manfaat yang diterima nasabah sesuai dengan apa yang telah diharapkan. Tarif di yang dibebankan nasabah BRI yang melakukan di agen BRILink menjadikan pengaruh pada tingkat kepuasan nasabah itu sendiri, karena setiap agen berhak untuk menentukan besaran biaya administrasi yang dibebankan oleh nasabah bank BRI yang akan melakukan 
transaksi di agen BRILink.Hasil penelitian Hendra Fure menunjukkan bahwa harga berpengaruh signifikan dan positif terhadap minat beli. Semakin tinggi harga, orang akan mempersiapkan jasa-jasa semakin tinggi, sehingga konsekuensinya akan meningkatkan nilai persepsi seseorang.Dengan demikian dengan adanya harga dapat membantu para pembeli untuk memutuskan cara mengalokasikan daya belinya pada berbagai jenis barang atau jasa[11].

Akan tetapi penelitian ini tidak sejalan dengan penelitian yang dilakukan oleh Jane Andoko [10] yang menyatakan bahwa variabel harga tidak berpengaruh signifikan terhadap minat konsumen.

Hal ini menunjukan bahwa harga memiliki kontribusi yang penting terhadap minat konsumen untuk bertansaksi di agen brilink.harga merupakan salah satu faktor terbesar yang meningkatkan minat konsumen untuk bertansaksi di Agen BRILink, dengan harga transaksi di Agen BRILink yang terjangkau, membuat konsumen berminat untuk bertansaksi di Agen BRILink. Harga yang ditawarkan Agen BRILink lebih murah di banding dengan Agen pelayanan sejenis, dan biaya jasa yang diwarakan sesuai dengan manfaat yang diberikan oleh Agen BRILink, sehingga minat konsumen dalam bertransaksi perbankan di Agen BRILink akan semakin meningkat.

Dalam mengenalkan produk serta jasa, BRI memiliki strategi-strategi dengan membuka layanan laku pandai yang dekat dengan masayarat dan memilih agen yang memiliki sebelumnya telah mimiliki usaha minimal satu tahun, sehingga produk dan jasa yang mereka miliki langsung dapat di kenal oleh msayarakat luas.

\section{Kesimpulan}

Adapun kesimpulan dari penelitian ini adalah :

1. Variabel tempat(X1), pelayanan(X2), dan harga(X3) secara simultan berpengaruh signifikan terhadap minat nasabah(Y) melakukan transaksi di BRILink.

2. Variabel tempat(X1) berpengaruh signifikan dan berhubungan positif terhadap minat nasabah(Y) melakukan transaksi di BRILink.

3. Variabel pelayanan(X2) tidak berpengaruh dan berhubungan negatif terhadap minat $\operatorname{nasabah}(\mathrm{Y})$ melakukan transaksi di BRILink.

4. Variabel harga(X3) berpengaruh signifikan dan berhubungan positif terhadap minat $\operatorname{nasabah}(\mathrm{Y})$ melakukan transaksi di BRILink. 
5. variabel tempat (X1) merupakan variabel yang paling dominan mempengaruhi minat nasabah dalam melakukan transaksi di agen BRILink dengan angka sumbangan efektif sebesar $35 \%$ dan sumbangan relatif sebesar 75,9\% di antara variabel pelayanan (X2) dan variabel harga (X3).

\section{Daftar Pustaka}

A. Faisol, "Pengaruh budaya, harga dan lokasi terhadap minat belanja konsumen di pasar soponyono," J. Ilmu dan Ris. Manejemen, vol. 5, no. L, 2016.

Bank BRI, "2016 Laporan Tahunan Kerja Nyata Bagi Negeri Membangun UMKM Unggu di Era Digital," 2016.

Faradiba and S. R. T. Astuti, "Analisis Pengaruh Kualitas Produk, Harga, Lokasi, Dan Kualitas Pelayanan Terhadap Minat Beli Ulang Konsumen (Studi pada Warung Makan 'Bebek Gendut' Semarang)," Diponegoro J. Manag., vol. 2, no. 3, pp. 1-11, 2013.

H. Fure, "LOKASI, KEBERAGAMAN PRODUK, HARGA, DAN KUALITAS PELAYANAN PENGARUHNYA TERHADAP MINAT BELI PADA PASAR TRADISIONAL BERSEHATI CALACA," J. Clin. Oncol., vol. 32, no. 27, p. 3083, 2014, doi: 10.1200/JCO.2014.56.8501.

J. Andoko and P. Devina, "ANALISIS PENGARUH MARKETING MIX (PRODUK, HARGA, PROMOSI, LOKASI) TERHADAP MINAT BELI KONSUMEN PADA GUEST HOUSE DI SURABAYA," J. Hosp. dan Manaj. Jasa, vol. 3, no. 2, pp. 5569, 2015, doi: 10.1017/CBO9781107415324.004.

Muntasir, "ANALISIS PENGARUH LOKASI DAN PELAYANAN PEGADAIAN SYARIAH TERHADAP MINAT NASABAH PADA PT. PEGADAIAN SYARIAH (PERSERO) CABANG CIKARANG," J. Lentera Akunt., vol. 2, no. 2, pp. 61-79, 2016.

N. L. Amita, "Pengaruh Persepsi Kegunaan, Persepsi Kemudahan, Persepsi Risiki Terhadap Minat Menggunakan Layanan Produk BRILink (Studi pada Masyarakat di Kota Kediri)," pp. 1-15, 2016.

O. Rakhmindyarto, P. Badan, K. Fiskal, and K. Keuangan, Keuangan Inklusif dan Pengentasan Kemiskinan. 2012.

P. RI, Peraturan Presiden Republik Indonesia Nomor 82 Tahun 2016 Tentang Strategi Nasional Keuangan Inklusif. Indonesia, 2017.

R. M. Reshita, "PENGARUH PROMOSI, LOKASI, DAN KUALITAS PELAYANAN TERHADAP MINAT MENABUNG NASABAH DI BANK BNI DI SIDOARJO,” 2015.

R. M. Kurniawan, H. Soesanto, and J. Sugiarto, "PENGARUH DAYA TARIK PRODUK, DAYA TARIK PELAYANAN, DAN DAYA SAING TARIF TERHADAP KEPUASAN NASABAH YANG BERDAMPAK PADA KEPUTUSAN BERTRANSAKSI (Studi pada Agen BRILink Bank BRI Cabang Pati),” pp. 1-20, 2017. 